\title{
Unparalleled Volatility in Sector-Wise Return in the Chittagong Stock Exchange: A Covid-19 Perspective
}

\author{
Nusrat Jahan* and Mohammad Nayeem Abdullah \\ CIU Business School \\ Chittagong Independent University, Bangladesh
}

\begin{abstract}
This study examined the effect of the Covid-19 health crisis on the volatility of sector-wise securities return listed in the Chittagong Stock Exchange (CSE) and compared this volatility with the pre-pandemic context. This study focused on the Chittagong Stock Exchange because this bourse offers a platform for negotiability and transferability of securities to investors in Chittagong and also plays a significant role in capital mobilization and the industrial development of Bangladesh. A sample of 90 securities under 19 sectors listed in the CSE were examined. The trend analysis indicated that Bank, Food, Footwear, Leasing, Life Insurance, Electrical and Engineering and Mutual Funds had same level of volatility between the Pre-Covid and Post-Covid time periods. Only four sectors, including Energy, Telecommunication, General Insurance and Miscellaneous sectors displayed a higher Post-Covid volatility relative to the Pre-Covid context. The result indicated that volatility of return was not the same for 19 sectors in the CSE over the selected time period. The researcher discovered that high and low periods of deaths had a significant impact on weekly volatility of return on 19 sectors of the CSE. However, the difference in volatility of return across all sectors between the Pre-Covid and Post-Covid time periods were not statistically significant from each other.
\end{abstract}

Keywords: volatility of return, stock market, covid-19

\section{ARTICLE INFO}

Article History:

Received: 5 May 2021

Accepted: 29 September 2021

Published: 1 December 2021

* Corresponding author: Nusrat Jahan: Email: mrs_ashfaque@yahoo.com 


\section{INTRODUCTION}

The economic growth of a nation depends on a strong and stable financial system that acts as a transmitting mechanism between savers and borrowers of funds. The significance of both banks and equity markets for economic development was advocated by Levine and Zervos (1998), Rajan and Zingles (2001) and Beck and Levine (2004). The capital market in Bangladesh consists of two full-fledged automated stock exchanges which are the Dhaka Stock Exchange (DSE) and the Chittagong Stock Exchange (CSE). The Bangladesh Securities and Exchange Commission (BSEC) regulates and monitors the stock exchanges of the country. The market capitalization of DSE to GDP and CSE to GDP in 2018 stood at 28 percent and 19 percent respectively (Capital Market Development, 2019). This indicator suggested a poorly developed stock market since the market capitalization was below 50 percent of GDP. The capital market of Bangladesh is not deep or broad enough to promote direct corporate financing through issuance of shares and bonds. Thus, financial system in Bangladesh is mostly dependent on banks for funding financing needs. Due to an inefficient intermediation by the banking system in Bangladesh, corporate financing is concentrated towards few sectors with high interest rates spread and maturity mismatch of assets and liabilities has become a common problem. The financial crisis in 1997 signified that dependency on banks as a single and major source of finance can aggravate economic slowdown. Hence, it is important for an economy to have multiple avenues for financial intermediation (Greenspan, 2000). Therefore, it is important to have an organized and stable stock market as an alternate source of cooperate financing comprising of both debt and equity instruments. Direct financing of business activities through issuance of shares is increasing slowly in the capital market in Bangladesh. However financing through corporate bonds is nonexistent. As of 2020, among the 3500 public limited companies in Bangladesh only 334 were listed in the DSE. The major challenge to the growth and development of the stock market in Bangladesh is an increased level of volatility hindering efficient functioning of the market. Since the financial turmoil of 1997, the BSEC has implemented a number of measures in terms of strict rules and guidelines, trading circuit breakers, international standard surveillance and disclosure requirements for both listed scripts and IPOs etc., in order to keep the stock market stable and attractive to general investors. Despite these investment-friendly regulatory reforms the stock market still remains 
volatile. General investors blame this continuing volatility to the lack of fairness and transparency that exists in the stock market in the form of market manipulation, insider trading and outright scams. Moreover, the existing instability of the stock market worsened further from February 2020, with the outbreak of the Covid-19 health crisis.

The novel Coronavirus, named by the WHO "Coronavirus disease 2019 or COVID-19" was first discovered at the end of December 2019 in the Hubei Province in central China. The COVID-19 rapid outbreak has led to rigorous containment measures by more than 100 countries worldwide. Several lockdown restrictions implemented by many counties have negatively impacted their social and economic activities (Nicola et al., 2020). The World Economic Outlook (WEO) projects of the International Monetary Fund suggested in April 2020 that the global economy is expected to descend sharply by -3 percent in 2020 due to the health crisis and the economic turmoil is expected to be much worse relative to the 2008-2009 financial crisis. The Covid-19 health crisis is also predicted to create widespread adverse impacts on the financial markets worldwide. The US stock market hit the circuit breaker mechanism four times in ten days during March 2020. Stock markets in Europe, Africa and Asia have also dropped sharply. During the period between February 2020 and June 2020, the Indian NIFTY 50 index fell by $37 \%$, the Pakistani KSE index plunged by $29 \%$, USA S\&P500 index fell by 33\%, Sri Lankan SPLK20LP index dropped by $41 \%$, BOVESPA index of Brazil plummeted by $44 \%$ and Chinese SSEC index declined by only $13 \%$. The already unstable stock market in Bangladesh was also shaken by the first reporting of three confirmed cases of Covid-19 on 8th March of 2020. A large numbers of investors started a selling spree on 10th March of 2020 in both the bourses in Dhaka and Chittagong, hence stock indices on both bourses went on a free fall. The bench mark index of the Dhaka bourse, plunged by 279 points or 6.5 percent on 10th March of 2020 which was the biggest ever single-day fall since the country's premier bourse launched this key index in January 2013. On March 19th of 2020, the BSEC launched a new circuit breaker to keep the stock market stable and to halt the free fall. While stock exchanges around the world were open despite the Corona Virus lockdowns, trading was stopped in the two bourses in Bangladesh from 26th March 2020 to 30th May 2020, marking it the longest trading halt since 1976. During the period between February 2020 and June 2020, the DSE recorded a negative index return of $-16 \%$ 
(Mahmud, 2020, January 2). However, at the end of August 2020, total turnover value of traded shares in the DSE and CSE were reported to be BDT 186.18 billion and BDT 5.94 billion respectively which were 210.23 percent and 70.02 percent higher respectively than that of the July 2020. The Broad index of the DSE and the all share price index of the CSE stood at 4879.15 points and 13908.14 points respectively at the end of August 2020 thus exhibiting an upward trend in these indices and turnover compared to the end of July 2020 (Capital Market Development, 2020).

The present study was carried out with the aim of examining the adverse effects of the Covid-19 health crisis on the volatility of securities returns and to compare the volatility to the Pre-Covid context. To fulfill the aim of this research, the researcher investigated the volatility of sectorwise returns of securities listed in the CSE from the perspective of the PreCovid and Post-Covid contexts. This study focused its investigation on the CSE because of its economic importance in the capital mobilization and industrial development of Bangladesh. Establishing a bourse in Chittagong enhanced liquidity for investors, who would otherwise be trapped in lengthy contracts with other financial intermediaries. In1995, the authorities felt this growing demand from investors and enterprises, to establish a stock market in Chittagong in addition to the existing and largest stock exchange of the country, the DSE. Hence on $1^{\text {st }}$ April of 1995, the CSE was incorporated which is now a completely automated exchange with a screen based trading facility and countrywide communication network. This exchange is operating with a mission to provide an effective, efficient and transparent platform of international standard for both local and foreign investors. This bourse is situated in the 'trade capital' or 'commercial hub' of Bangladesh, i.e. Chittagong, which holds the status of being the second largest economy in the country, only behind the Dhaka Division. A substantial share of the nation's nominal GDP of about 12\% was attributed to Chittagong in 2020. The geographic location across the Bay of Bengal had made it strategically, internationally, geopolitically, and significantly important as well. The port activity has been growing consistently due to the rise in the economy of the country and international connectivity. Realizing the viability and strategic importance of this port city which is on the verge of becoming a megacity, the policy makers in the country have already rushed to adopt an array of farsighted and long-term plans to tab the full potential of this city. Accordingly, the infrastructural development projects including the 
Mirsarai Economic Zone, the Karnaphuli Tunnel- the under-construction underwater expressway tunnel under the Kanaphuli river, Elevated express highway up to the airport, Matarbari power plant project, construction of Bay terminal, and LNG terminal, construction of Chittagong-Cox's bazar railway line, converting the Cox's Bazar Airport into an international one, enhancing the capacity of the port and others are expected to strengthen the communications and connectivity of the city yet further as well as enhance the manifold of economic activities (The Chittagong Chamber of Commerce and Industry, n.d.). Upon successful completion of the said projects, it is expected that a large number of foreign direct investment and local enterprises would enhance their investments in this region. This study chose to investigate the volatility of return of securities listed in the CSE because such developments in Chittagong would usher in a new hope for the CSE in future.

\section{EMPIRICAL LITERATURE}

Investors tend to display collective behavior in response to positive or negative news and change in macro-economic conditions. This herding behavior of investors is observed in previous cases of disease outbreaks and also during the recent Covid-19 pandemic. Many researchers have already studied the impact of the pandemic on specific stock markets across significant global economies. The following discussion lists a few that have been undertaken to investigate the effect of the Corona Virus health crisis on stock markets.

Yousef (2020) investigated the impact of the outbreak on stock market volatility for the major $\mathrm{G} 7$ stock market indices. The analysis consisted of assessing the impact of the pandemic on the standard deviations of the seven indices using the Generalized Autoregressive Conditional Heteroskedasticity (GARCH) and the Glosten-Jagannathan-Runkle GARCH (GJR-GARCH) models. This study found that the minimum value for each index occurred in March-2020, with all indices reaching 20-year lows during this month, with the exception of Japan (Nikkei 225). Furthermore, the results of the regression analysis revealed that the COVID-19 dummy variable, the number of daily new cases, and the growth rate of daily new cases all had a significant positive impact on the G7 stock market volatility. Finally, the 
GARCH and GJR-GARCH models revealed that the COVID-19 coefficients in the conditional variance equation had a significant positive impact on the conditional variance for all seven stock indices, further indicating that COVID-19 had increased market volatility. Ibrahim et al. (2020) studied the relationship between COVID-19, government response measures, and stock market volatilities for 11 developed and developing economies within the Asia-Pacific region from 15 February-30 May 2020. This study employed the continuous wavelet transformation (CWT) analysis and plots and the GJR-GARCH analysis and examined the effects of the COVID-19 public health crisis and the corresponding government measures on the respective domestic equity markets volatilities. This study reported that all the sample countries, except Japan, experienced very low or low volatility over the short-term horizons, while, Vietnam, Malaysia, and Laos experienced medium volatility over the medium-term horizons. China, Japan, South Korea, Malaysia, and the Philippines experienced high volatility over the long-term horizons. A similar comprehensive study on the impact of COVID-19 on the stock return volatility in 15 countries was carried out by Kusumahadi and Permana (2021) from January 2019 to June 2020. This study found that changes in exchange rates had negatively affected stock returns in most countries. Based on the threshold generalized autoregressive conditional heteroskedasticity regressions, this study found evidence that the emergence of COVID-19 affected stock return volatility in all observed countries except the United Kingdom. However, this research indicated the magnitude of this effect as small in every observed country. This finding suggests the need for in-depth studies of other factors that affect stock return volatility besides the occurrence of COVID-19. Uddin et al. (2021) examined data from 34 developed and emerging markets to see if economic strength, measured by a set of selected country-level economic characteristics and factors can potentially mitigate the possible detrimental effect of the global pandemic on stock market volatility. This study found that these country-level economic characteristics and factors such as economic resilience, intensity of capitalism, level of corporate governance, financial development, monetary policy rates and quality of the health system help in reducing the volatility arising due to the pandemic.

Bahrini and Filfilan (2020) investigated the impact of the COVID-19 confirmed cases and deaths on the daily returns of the major stock market indices in the Gulf Cooperation Council (GCC) countries from April 
1,2020 to June 26,2020 by using panel data regression analysis. This study found that stock markets in the GCC countries responded negatively and with a great degree to new and total COVID-19 confirmed deaths, while response to the number of COVID-19 confirmed cases was not significant. During the COVID-19 outbreak daily returns of the major stock market indices in the GCC countries declined as the number of confirmed deaths increased. This study also suggested that GCC stock markets were impacted positively by crude oil prices (WTI) and negatively by the variation of the implied volatility in the global oil markets and the global stock markets. A comparable analysis of the impact of the pandemic between the DSE and the CSE was conducted by Haque and Chowdhury (2020). The study found both DSEX and CSE all share price (CASPI) index to fall sharply on March 2020 and market capitalization also dropped during the same period. The study indicated that both the indices, trade volume and market capitalization showed a positive trend in June 2020. This study criticized the closure of stock market operations for almost two months during the Pandemic and also indicated that the introduction of a floor price had created confusion among the general investors. A country specific study similar to this was conducted by Bora and Batish (2021) who investigated the impact of COVID-19 on the volatility of stock prices in India with the help of a generalized autoregressive conditional heteroskedasticity model from September 3, 2019 to July 10, 2020. This study compared stock price returns of Pre-COVID- 19 and during the COVID-19 situation and revealed that the stock market in India has experienced volatility during the pandemic. While comparing the result during the COVID period with that of the Pre-COVID, it was found that the return on the indices was higher in the Pre-COVID-19 period than during the COVID-19 period.

Hong et al. (2021) studied the relationship between the Pandemic and the instability of both stock return predictability and price volatility in the U.S from1st, 2019 to June 30th, 2020. The results highlighted a single break in return predictability and price volatility of both the Standard \& Poor's 500 (S\&P 500) and the Dow Jones Industrial Average (DJIA). The timing of the break was consistent with the COVID-19 outbreak, or more specifically the stock selling offs by the U.S. senate committee members before the COVID-19 situation crashed the market. The findings suggested that the Crisis was associated with market inefficiency, creating profitable opportunities for traders and speculators. The effect of Covid-19 Pandemic 
on the US stock market volatility was also examined by Baek et al. (2020). This study found that volatility was affected by specific economic indicators and was sensitive to COVID-19 news. The study discovered both negative and positive COVID-19 information as significant, though negative news was more impactful, suggesting a negativity bias.

This study contributes to the quickly expanding research on the effect of the Pandemic on the stock market by focusing on developing economies like Bangladesh which is already enduring instability in its capital market. A few research undertaken in the context of Bangladesh such as by Haque and Chowdhury (2020) discussed the trend of quantitative indicators reported on the capital market development report published by the Research Department of Bangladesh Bank. However, this research utilized the current market price of securities listed under each sector of the CSE for the selected pre-pandemic and post-pandemic period and estimated the sector-wise volatility and investigated whether the difference in volatility was significant between two periods and among sectors. Therefore, in this study the aim of the researcher was to discover whether the recent volatility is parallel or unparallel to the pre-pandemic situation.

\section{OBJECTIVES OF THE STUDY}

The specific objectives of the study were as follows:

1. Evaluating the trend of Pre-Covid and Post-Covid volatility of returns on all the sectors in the CSE.

2. Assessing the equivalency of volatility of returns on all the sectors of the CSE over the selected time period.

3. Evaluating the differences in volatility of returns on all the sectors of the CSE between the Pre-Covid and Post-Covid periods.

4. Assessing the effect of high or low periods of Covid 19 deaths on the volatility of returns on all the sectors of the CSE. 


\section{RESEARCH METHODOLOGY}

\section{Research Approach}

Employing a positivist view this study followed a deductive approach to conduct the research because data was mainly quantitative and collected through a structured procedure from the selected sample and hypotheses were developed and tested to explain the relationship and make generalizations. Both descriptive and parametric inferential statistics were used for data analysis. Inferential statistics were used to generalize the findings of the sample to the population it represented.

\section{Sources and Measurement of Data}

This study used data of all sectors or industries in accordance with the classification of the CSE. A sample of 90 securities under 19 sectors or industries were selected randomly. There were only 3 securities listed under the category of Telecommunication and 2 securities under the category of Corporate Bonds in the CSE. Except for Telecommunications and Corporate Bonds, from the remaining 17 sectors 5 securities were randomly selected from each sector for analysis. Post-covid-data on closing price of securities were generated for 35 weeks from March 2020 to March 2021 during the weeks of active trading days of the CSE. Pre-Covid data on securities prices were generated for 35 weeks starting from May 2019 to February 2020. Number of weekly Covid 19 deaths for the periods of active trading weeks of the CSE was collected from the Reuters website. Weekly standard deviations of returns of all the 90 securities and the mean weekly standard deviations of return of each sector was calculated to assess the volatility of returns during the Post-Covid and Pre-Covid time period. Descriptive statistics used included arithmetic mean, minimum, maximum, standard deviation and trend analysis. Parametric test statistics employed were the one-way ANOVA and one-way MANOVA, and the independent sample t-test. This study employed a line chart to show the comparative trends in volatility of 19 sectors during the Pre-Covid and Post-Covid period to fulfill the first objective. 


\section{Hypotheses Formulation}

The hypothesis that the estimate is based solely on chance is called the null hypothesis. Since the sample of this study contained only a subset of the data in the population, the researcher could not ascertain whether the null hypothesis was true or not (Zaiontz, 2020). Hence, the researcher gathered data to reject, nullify or disprove the null hypothesis on the basis of some tests, but not with the intention of accepting the null hypothesis.

\section{Hypothesis I}

The study formulates the following null hypothesis to assess the equivalency of volatility of returns on all sectors of the CSE over the selected time period.

$\mathbf{H}_{10}$ : There exists no difference in the volatility of returns on all sectors over the selected time period.

The researcher investigated data covering the Pre-Pandemic and Post-Pandemic situation. Over the selected period, especially during the times when the government had restricted economic activities to control the movement of people, most sectors were not allowed to conduct manufacturing and render services. However, certain sectors such as the garments and export oriented industries, utility, hospitals and banking institutions were excluded for such closures; hence a differing level of productivity across all the sectors was expected to create disparate levels of volatility in the market price of securities. Hence, the researcher proposed the first null hypothesis with the expectation of rejecting it. For testing the first null hypothesis the One-way Analysis of Variance (ANOVA) was used. ANOVA determines whether there are any statistically significant differences between the means of three or more independent (unrelated) groups which were the 19 sectors listed in the CSE.

\section{Hypothesis II}

The study formulated the following null hypothesis to evaluate the differences in volatility of return on all sectors of the CSE between the Pre-Covid and Post-Covid periods.

$\mathbf{H}_{\mathbf{2 0}}$ : There exists no difference in volatility on returns on all sectors during the Pre-Covid and Post-Covid periods. 
The researcher anticipated that many people lost jobs, faced temporary unemployment and pay cuts due to the closure of most manufacturing and service sectors including the stock exchanges during the Post-Covid context, investors will be restraining themselves from making new investments in the stock market and likely to withdraw funds invested in securities to meet their shortfall of cash or to control capital loss. Hence, the instability of security prices was anticipated to be high compared to the Pre-Pandemic context. With this anticipation, the researcher proposed the second null hypothesis and tested the same by the Independent Sample T-test with the intention of nullifying it. This test compares the means of two independent groups, that is, the mean standard deviation of returns during the Pre-Covid and Post-Covid time period, in order to determine whether there is statistical evidence that the associated population means are significantly different from each other.

\section{Hypothesis III}

The study formulated the following null hypothesis to assess the effect of high or low periods of Covid 19 deaths on the volatility of returns on all the sectors of the CSE.

$\mathbf{H}_{30}$ : There is no difference in volatility of returns in each sector due to high or low number of deaths.

The researcher predicted that returns from securities will face more instability during high number of Covid 19 deaths since the stock market is susceptible to market information. Hence, the researcher proposed the third null hypothesis with the prospect of disproving it. The third null hypothesis wad tested by the Multivariate analysis of variance (MANOVA) which indicates whether or not the independent grouping variable in terms of high and low period of deaths can explain a statistically significant amount of variance in the multiple continuous dependent variables which were the 19 sectors of the CSE. 


\section{FINDINGS AND ANALYSIS}

\section{Trend of Pre-Covid and Post-Covid Volatility of Returns for all Sectors}

Table 1 and Table 2 reports the mean standard deviation of returns or volatility of returns during the selected 35 weeks of the Pre-Covid and 35 weeks of the Post-Covid time period. The mean standard deviation of returns is reported for all the 19 sectors listed in the CSE.

Table 1: Summary of 35 Weeks Return of all Sectors Listed in CSE

\begin{tabular}{cccccccccc}
\hline & Bank & Cement & Ceramic & Energy & Food & Foot-wear & Paper & Pharma & Telecom \\
\hline Pre-covid & 0.020 & 0.031 & 0.032 & 0.019 & 0.023 & 0.012 & 0.034 & 0.026 & 0.015 \\
Post-covid & 0.021 & 0.023 & 0.022 & 0.021 & 0.022 & 0.012 & 0.022 & 0.024 & 0.030 \\
\hline \multicolumn{2}{l}{ Source: Authors' Calculation }
\end{tabular}

Table 2: Summary of 35 Weeks Return of all Sectors Listed in CSE

\begin{tabular}{lllllllllll} 
& Textile & ICT & $\begin{array}{c}\text { Gen__ } \\
\text { Insur }\end{array}$ & Leasing & $\begin{array}{l}\text { Life_ } \\
\text { Insur }\end{array}$ & Services & $\begin{array}{c}\text { Elec \& } \\
\text { Eng }\end{array}$ & $\begin{array}{c}\text { Corp_ } \\
\text { Bond }\end{array}$ & $\begin{array}{c}\text { Mut_ } \\
\text { Fund }\end{array}$ & Misc. \\
\hline pre-covid & 0.033 & 0.029 & 0.030 & 0.025 & 0.026 & 0.021 & 0.026 & 0.023 & 0.025 & 0.026 \\
post-covid & 0.022 & 0.026 & 0.035 & 0.026 & 0.026 & 0.019 & 0.025 & 0.010 & 0.026 & 0.028 \\
\hline \multicolumn{2}{l}{ Source: Authors' Calculation } & & & & & & & &
\end{tabular}

Figure 1 reports the trend in volatility of return for all sectors between the two selected time periods through a line chart. This chart demonstrates that the ups and downs in volatility of returns were almost the same for a few sectors, including Bank, Food, Footwear, Leasing, Life Insurance, Electrical and Engineering and Mutual Funds, during the Pre-Covid and Post-Covid time period. However, the Pre-covid volatility of sector-wise returns were found to be higher than the Post-Covid volatility of returns for few sectors such as Cement, Ceramic, Paper, Pharmaceuticals, Textile, ICT, Services and Corporate bonds. The Post-Covid volatility of returns was highest for Energy, Telecommunication, General Insurance and the Miscellaneous sectors. The chart indicates that the Pre-Covid volatility of returns remained generally higher than the Post-Covid volatility of sectorwise returns while the opposite was anticipated given the health crisis occurring due to the Covid-19 Pandemic. 


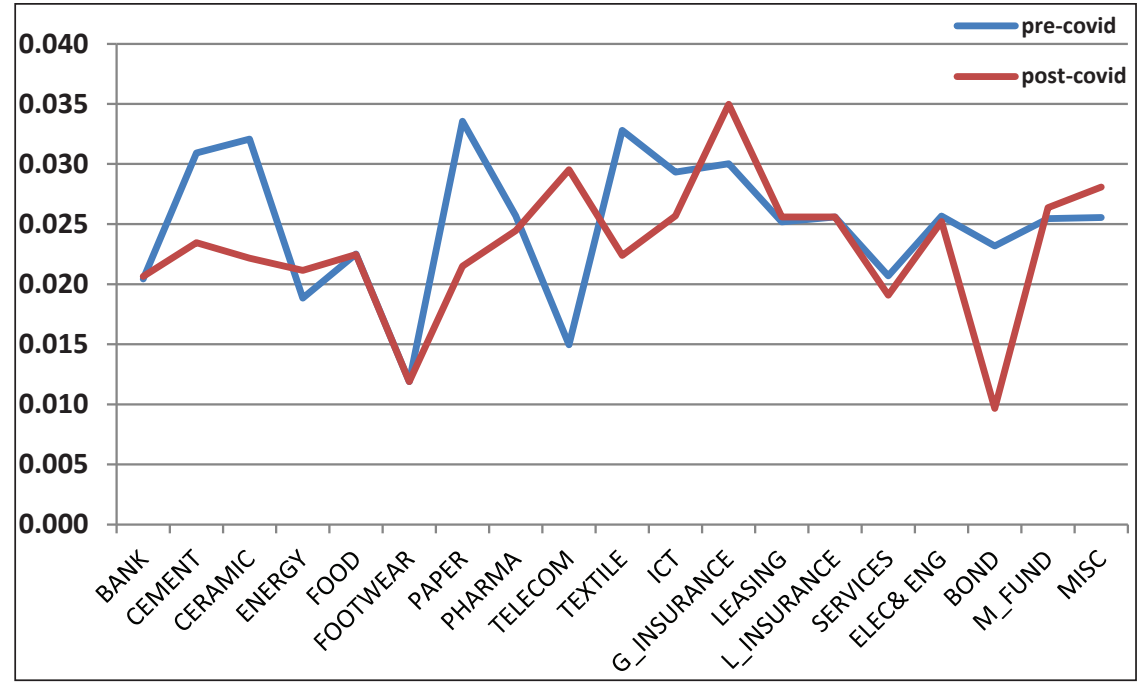

Figure 1: Trend of Pre-covid and Post-covid Volatility of Return of all Sectors

\section{Equivalency of Volatility of Returns Across Different Sectors}

Descriptive statistics for ANOVA reported in Table 3 details the mean, standard deviation and maximum and minimum values of weekly standard deviations of returns for 19 sectors in the CSE. The sample size constituted of 70 active trading weeks in the CSE from May 2019. The Table shows a relatively higher mean volatility of s for eleven sectors which were Cement, Ceramic, Paper, Pharmaceuticals, Textile, ICT, General Insurance, Leasing, Life Insurance, Electrical and Engineering and Mutual Funds. Descriptive statistics also report a standard deviation of volatility of returns across 70 weeks for each sector listed in the CSE.

Table 3: Descriptive Statistics for ANOVA

\begin{tabular}{lcccccc}
\hline & N & Mean & $\begin{array}{c}\text { Std. } \\
\text { Deviation }\end{array}$ & $\begin{array}{c}\text { Std. } \\
\text { Error }\end{array}$ & Minimum & Maximum \\
\hline Bank & 70 & 0.021 & 0.009 & 0.001 & 0.000 & 0.052 \\
Cement & 70 & 0.027 & 0.013 & 0.002 & 0.000 & 0.067 \\
Ceramic & 70 & 0.026 & 0.011 & 0.001 & 0.014 & 0.072 \\
Energy & 70 & 0.017 & 0.006 & 0.001 & 0.008 & 0.048 \\
Food & 70 & 0.014 & 0.011 & 0.001 & 0.006 & 0.050 \\
Footwear & 70 & 0.017 & 0.009 & 0.001 & 0.000 & 0.053
\end{tabular}




\begin{tabular}{lcccccc} 
Paper & 70 & 0.029 & 0.011 & 0.001 & 0.013 & 0.087 \\
Pharmaceuticals & 70 & 0.023 & 0.008 & 0.001 & 0.013 & 0.061 \\
Telecom & 70 & 0.013 & 0.005 & 0.001 & 0.008 & 0.040 \\
Textile & 70 & 0.029 & 0.010 & 0.001 & 0.016 & 0.091 \\
ICT & 70 & 0.024 & 0.010 & 0.001 & 0.012 & 0.058 \\
Gen_Insurance & 70 & 0.030 & 0.006 & 0.001 & 0.010 & 0.050 \\
Leasing & 70 & 0.024 & 0.009 & 0.001 & 0.010 & 0.085 \\
Life Insurance & 70 & 0.025 & 0.011 & 0.001 & 0.000 & 0.080 \\
Services & 70 & 0.016 & 0.008 & 0.001 & 0.009 & 0.056 \\
Elec \& Eng & 70 & 0.022 & 0.008 & 0.001 & 0.014 & 0.054 \\
Corp_Bond & 70 & 0.010 & 0.004 & 0.000 & 0.001 & 0.023 \\
Mutual Fund & 70 & 0.021 & 0.008 & 0.001 & 0.015 & 0.049 \\
Miscellaneous & 70 & 0.020 & 0.010 & 0.001 & 0.010 & 0.058 \\
Total & 1330 & 0.021 & 0.011 & 0.000 & 0.000 & 0.091 \\
\hline
\end{tabular}

Source: Authors' Calculation

The results of the one-way ANOVA as reported in Table 4 was used to test the first null hypothesis (H1o) that stated that there exists no difference among the mean standard deviation of returns among all sectors over the selected time period. The test result indicates whether the differences in mean values are statistically significant or not. The test result as reported in Table 4 indicates that the estimated value of ' $\mathrm{F}$ ' that is 28.184 is statistically significant at the 0.05 level of significance since the estimated $\mathrm{P}$ value is less than 0.05 . Hence, this study rejected the first null hypothesis (H1o), thus implying that the differences that exist among the mean volatility of returns across 19 sectors over the selected 70 weeks period were statistically significant. Therefore, this result suggested that the mean standard deviation of returns were not same for 19 sectors in the CSE over the selected time period.

Table 4: Result of ANOVA for Mean Volatility of Return across Different Sectors

\begin{tabular}{lccccc} 
& $\begin{array}{c}\text { Sum of } \\
\text { Squares }\end{array}$ & df & $\begin{array}{c}\text { Mean } \\
\text { Square }\end{array}$ & F & Sig. \\
\cline { 1 - 4 } Between Groups & 0.042 & 18.000 & 0.002 & 28.184 & 0.000 \\
\cline { 1 - 5 } Within Groups & 0.108 & 1311.000 & 0.000 & & \\
\cline { 1 - 5 } Total & 0.150 & 1329.000 & & & \\
\hline
\end{tabular}

Source: Authors' Calculation 


\section{Differences in Volatility of Returns between the Pre-Covid and Post-Covid periods}

Descriptive statistics in Table 5 reports the mean standard deviation of returns for 5 enterprises under each sector listed in the CSE, except for Telecommunications and Corporate bonds, over the 35 weeks of the Pre-Covid and 35 weeks of the Post-Covid time period. Under the Telecommunications and Corporate Bonds sectors there were only 3 and 2 securities listed respectively in the CSE. Descriptive statistics reports that mean standard deviation of returns for all the sectors listed were found to be relatively higher in the Pre-Covid period compared to the Post-Covid period. Descriptive statistics also report a standard deviation of volatility of returns of selected securities under each sector during the Pre-Covid and Post-Covid time period.

Table 5: Descriptive Statistics for Independent Sample t-test

\begin{tabular}{llllll}
\hline & Time Period & N & Mean & $\begin{array}{c}\text { Std. } \\
\text { Deviation }\end{array}$ & $\begin{array}{c}\text { Std. Error } \\
\text { Mean }\end{array}$ \\
\hline Bank_SD & Pre_Covid & 5 & 0.020 & 0.003 & 0.001 \\
Cement_SD & Post_Covid & 5 & 0.021 & 0.003 & 0.001 \\
Ceramic_SD & Pre_Covid & 5 & 0.031 & 0.011 & 0.005 \\
Energy_SD & Post_Covid & 5 & 0.023 & 0.008 & 0.004 \\
Food_SD & Pre_Covid & 5 & 0.032 & 0.008 & 0.004 \\
& Post_Covid & 5 & 0.022 & 0.013 & 0.006 \\
Footwear_SD & Pre_Covid & 5 & 0.019 & 0.005 & 0.002 \\
Paper_SD & Post_Covid & 5 & 0.021 & 0.006 & 0.003 \\
& Pre_Covid & 5 & 0.023 & 0.014 & 0.006 \\
Pharmaceuticals_SD & Post_Covid & 5 & 0.022 & 0.014 & 0.006 \\
& Pre_Covid & 5 & 0.012 & 0.009 & 0.004 \\
Textile_SD & Post_Covid & 5 & 0.012 & 0.009 & 0.004 \\
& Pre_Covid & 5 & 0.034 & 0.006 & 0.003 \\
ICT_SD & Post_Covid & 5 & 0.022 & 0.010 & 0.004 \\
& Post_Covid & 5 & 0.026 & 0.003 & 0.001 \\
Gen_Insurance_SD & Pre_Covid & 5 & 0.024 & 0.009 & 0.004 \\
& Post_Covid & 5 & 0.033 & 0.006 & 0.003 \\
Leasing & Pre_Covid & 5 & 0.022 & 0.010 & 0.005 \\
& Post_Covid & 5 & 0.029 & 0.005 & 0.002 \\
& Post_Covid & 5 & 0.035 & 0.004 & 0.002 \\
& Pre_Covid & 5 & 0.025 & 0.004 & 0.002 \\
& & 5 & 0.030 & 0.010 & 0.002 \\
& & & &
\end{tabular}




\begin{tabular}{lllccc}
\hline & Time Period & N & Mean & $\begin{array}{c}\text { Std. } \\
\text { Deviation }\end{array}$ & $\begin{array}{c}\text { Std. Error } \\
\text { Mean }\end{array}$ \\
\hline \multirow{3}{*}{ Life_Insurance_SD } & Post_Covid & 5 & 0.026 & 0.011 & 0.005 \\
& Pre_Covid & 5 & 0.026 & 0.011 & 0.005 \\
& Post_Covid & 5 & 0.026 & 0.011 & 0.005 \\
Elec_Eng_SD & Pre_Covid & 5 & 0.021 & 0.005 & 0.002 \\
& Post_Covid & 5 & 0.019 & 0.008 & 0.004 \\
Mutual Fund_SD & Pre_Covid & 5 & 0.026 & 0.004 & 0.002 \\
& Post_Covid & 5 & 0.025 & 0.005 & 0.002 \\
Miscellaneous & Pre_Covid & 5 & 0.025 & 0.005 & 0.002 \\
& Post_Covid & 5 & 0.026 & 0.003 & 0.001 \\
Telecom_SD & Pre_Covid & 5 & 0.026 & 0.004 & 0.002 \\
& Post_Covid & 5 & 0.028 & 0.008 & 0.004 \\
Corp_Bond_SD & Pre_Covid & 3 & 0.015 & 0.013 & 0.008 \\
& Post_Covid & 3 & 0.030 & 0.015 & 0.009 \\
& Pre_Covid & 2 & 0.008 & 0.000 & 0.000 \\
& Post_Covid & 2 & 0.010 & 0.004 & 0.003 \\
\hline
\end{tabular}

Source: Authors' Calculation

Levene's Testreported in Table 6 checked the homogeneity of variance assumption. The T-test assumes that the variance is the same in both the samples that is the variance reported by the standard deviation of volatility of returns during the Pre-Covid and Post Covid time period are not significantly different from each other. Levene's test was used to check this homogeneity of variance assumption to endorse the result of t-test. The results of Levene's test in Table 6 shows that the estimated value of $F$ was not statistically significant for 16 sectors except for Services, Corporate Bonds and the Miscellaneous sector. The estimated value of $P$ was more than the 0.05 level of significance meant that the standard deviation of volatility of returns was not significantly different between the two samples. Only three sectors listed in the CSE violated the assumption of equality of variance under the t-test. However, the t-test for the independent groups were robust to the violation of this assumption, hence a reported t-value can be used to test the second null hypothesis $(\mathrm{H} 2 \mathrm{o})$ that stated that there exists no difference in volatility of returns for all sectors between the Pre-Covid and Post-Covid time period. The reported t-value as shown in Table 6 was not statistically significant since the estimated $\mathrm{P}$ value was more than the 0.05 level of significance for all sectors in the CSE. Hence, the result failed to reject the second null hypothesis. This finding implied that the difference in time period created no difference in volatility of returns for selected securities. 
Table 6: Result of Independent Sample t-test

\begin{tabular}{|c|c|c|c|c|c|c|c|}
\hline & & \multicolumn{2}{|c|}{$\begin{array}{l}\text { Levene's Test } \\
\text { for Equality of } \\
\text { Variances }\end{array}$} & \multirow[b]{2}{*}{$t$} & \multirow[b]{2}{*}{ df } & \multirow[b]{2}{*}{$\begin{array}{c}\text { Sig. } \\
\text { (2-tailed) }\end{array}$} & \multirow[b]{2}{*}{$\begin{array}{c}\text { Mean } \\
\text { Difference }\end{array}$} \\
\hline & & $\mathbf{F}$ & Sig. & & & & \\
\hline \multirow[t]{2}{*}{ Bank_SD } & $\begin{array}{l}\text { Equal variances } \\
\text { assumed }\end{array}$ & 0.025 & 0.879 & -0.108 & 8.000 & 0.916 & 0.000 \\
\hline & $\begin{array}{l}\text { Equal variances not } \\
\text { assumed }\end{array}$ & & & -0.108 & 7.978 & 0.916 & 0.000 \\
\hline \multirow[t]{2}{*}{ Cement_SD } & $\begin{array}{l}\text { Equal variances } \\
\text { assumed }\end{array}$ & 1.148 & 0.315 & 1.248 & 8.000 & 0.247 & 0.008 \\
\hline & $\begin{array}{l}\text { Equal variances not } \\
\text { assumed }\end{array}$ & & & 1.248 & 7.505 & 0.250 & 0.008 \\
\hline \multirow[t]{2}{*}{ Ceramic_SD } & $\begin{array}{l}\text { Equal variances } \\
\text { assumed }\end{array}$ & 3.841 & 0.086 & 1.417 & 8.000 & 0.194 & 0.010 \\
\hline & $\begin{array}{l}\text { Equal variances not } \\
\text { assumed }\end{array}$ & & & 1.417 & 6.584 & 0.202 & 0.010 \\
\hline \multirow[t]{2}{*}{ Energy_SD } & $\begin{array}{l}\text { Equal variances } \\
\text { assumed }\end{array}$ & 0.593 & 0.463 & -0.652 & 8.000 & 0.533 & -0.002 \\
\hline & $\begin{array}{l}\text { Equal variances not } \\
\text { assumed }\end{array}$ & & & -0.652 & 7.407 & 0.534 & -0.002 \\
\hline \multirow[t]{2}{*}{ Food_SD } & $\begin{array}{l}\text { Equal variances } \\
\text { assumed }\end{array}$ & 0.023 & 0.884 & 0.004 & 8.000 & 0.997 & 0.000 \\
\hline & $\begin{array}{l}\text { Equal variances not } \\
\text { assumed }\end{array}$ & & & 0.004 & 7.999 & 0.997 & 0.000 \\
\hline \multirow[t]{2}{*}{ Footwear_SD } & $\begin{array}{l}\text { Equal variances } \\
\text { assumed }\end{array}$ & 0.000 & 1.000 & 0.000 & 8.000 & 1.000 & 0.000 \\
\hline & $\begin{array}{l}\text { Equal variances not } \\
\text { assumed }\end{array}$ & & & 0.000 & 8.000 & 1.000 & 0.000 \\
\hline \multirow[t]{2}{*}{ Paper_SD } & $\begin{array}{l}\text { Equal variances } \\
\text { assumed }\end{array}$ & 0.431 & 0.530 & 2.348 & 8.000 & 0.047 & 0.012 \\
\hline & $\begin{array}{l}\text { Equal variances not } \\
\text { assumed }\end{array}$ & & & 2.348 & 6.677 & 0.053 & 0.012 \\
\hline \multirow[t]{2}{*}{ Pharma_SD } & $\begin{array}{l}\text { Equal variances } \\
\text { assumed }\end{array}$ & 5.410 & 0.048 & 0.277 & 8.000 & 0.789 & 0.001 \\
\hline & $\begin{array}{l}\text { Equal variances not } \\
\text { assumed }\end{array}$ & & & 0.277 & 4.621 & 0.794 & 0.001 \\
\hline \multirow[t]{2}{*}{ Textile_SD } & $\begin{array}{l}\text { Equal variances } \\
\text { assumed }\end{array}$ & 1.915 & 0.204 & 1.957 & 8.000 & 0.086 & 0.010 \\
\hline & $\begin{array}{l}\text { Equal variances not } \\
\text { assumed }\end{array}$ & & & 1.957 & 6.180 & 0.097 & 0.010 \\
\hline \multirow[t]{2}{*}{ ICT_SD } & $\begin{array}{l}\text { Equal variances } \\
\text { assumed }\end{array}$ & 0.545 & 0.482 & 1.211 & 8.000 & 0.260 & 0.004 \\
\hline & $\begin{array}{l}\text { Equal variances not } \\
\text { assumed }\end{array}$ & & & 1.211 & 7.609 & 0.262 & 0.004 \\
\hline \multirow[t]{2}{*}{ Gen_Ins_SD } & $\begin{array}{l}\text { Equal variances } \\
\text { assumed }\end{array}$ & 2.218 & 0.175 & -0.994 & 8.000 & 0.349 & -0.005 \\
\hline & $\begin{array}{l}\text { Equal variances not } \\
\text { assumed }\end{array}$ & & & -0.994 & 5.175 & 0.364 & -0.005 \\
\hline
\end{tabular}




\begin{tabular}{|c|c|c|c|c|c|c|c|}
\hline & & \multicolumn{2}{|c|}{$\begin{array}{l}\text { Levene's Test } \\
\text { for Equality of } \\
\text { Variances }\end{array}$} & \multirow[b]{2}{*}{$\mathbf{t}$} & \multirow[b]{2}{*}{ df } & \multirow[b]{2}{*}{$\begin{array}{c}\text { Sig. } \\
\text { (2-tailed) }\end{array}$} & \multirow[b]{2}{*}{$\begin{array}{c}\text { Mean } \\
\text { Difference }\end{array}$} \\
\hline & & $\mathbf{F}$ & Sig. & & & & \\
\hline \multirow[t]{2}{*}{ Leasing } & $\begin{array}{l}\text { Equal variances } \\
\text { assumed }\end{array}$ & 2.203 & 0.176 & -0.077 & 8.000 & 0.941 & 0.000 \\
\hline & $\begin{array}{l}\text { Equal variances not } \\
\text { assumed }\end{array}$ & & & -0.077 & 4.845 & 0.942 & 0.000 \\
\hline \multirow[t]{2}{*}{ Life_Ins_SD } & $\begin{array}{l}\text { Equal variances } \\
\text { assumed }\end{array}$ & 0.000 & 1.000 & 0.000 & 8.000 & 1.000 & 0.000 \\
\hline & $\begin{array}{l}\text { Equal variances not } \\
\text { assumed }\end{array}$ & & & 0.000 & 8.000 & 1.000 & 0.000 \\
\hline \multirow[t]{2}{*}{ Services_SD } & $\begin{array}{l}\text { Equal variances } \\
\text { assumed }\end{array}$ & 6.291 & 0.036 & 0.369 & 8.000 & 0.722 & 0.002 \\
\hline & $\begin{array}{l}\text { Equal variances not } \\
\text { assumed }\end{array}$ & & & 0.369 & 6.306 & 0.724 & 0.002 \\
\hline \multirow[t]{2}{*}{ Elec \&Eng_SD } & $\begin{array}{l}\text { Equal variances } \\
\text { assumed }\end{array}$ & 1.336 & 0.281 & 0.165 & 8.000 & 0.873 & 0.001 \\
\hline & $\begin{array}{l}\text { Equal variances not } \\
\text { assumed }\end{array}$ & & & 0.165 & 7.501 & 0.874 & 0.001 \\
\hline \multirow[t]{2}{*}{ M_Fund_SD } & $\begin{array}{l}\text { Equal variances } \\
\text { assumed }\end{array}$ & 1.188 & 0.307 & -0.388 & 8.000 & 0.708 & -0.010 \\
\hline & $\begin{array}{l}\text { Equal variances not } \\
\text { assumed }\end{array}$ & & & -0.388 & 6.474 & 0.711 & -0.010 \\
\hline \multirow[t]{2}{*}{ Misc. } & $\begin{array}{l}\text { Equal variances } \\
\text { assumed }\end{array}$ & 10.522 & 0.012 & -0.614 & 8.000 & 0.556 & -0.003 \\
\hline & $\begin{array}{l}\text { Equal variances not } \\
\text { assumed }\end{array}$ & & & -0.614 & 5.471 & 0.564 & -0.003 \\
\hline \multirow[t]{2}{*}{ Telecom_SD } & $\begin{array}{l}\text { Equal variances } \\
\text { assumed }\end{array}$ & 0.001 & 0.974 & -1.257 & 4.000 & 0.277 & 0.015 \\
\hline & $\begin{array}{l}\text { Equal variances not } \\
\text { assumed }\end{array}$ & & & -1.257 & 3.963 & 0.278 & 0.015 \\
\hline \multirow[t]{2}{*}{ Bond_SD } & $\begin{array}{l}\text { Equal variances } \\
\text { assumed }\end{array}$ & $5^{\star} 10^{16}$ & 0.000 & -0.437 & 2.000 & 0.704 & 0.001 \\
\hline & $\begin{array}{l}\text { Equal variances not } \\
\text { assumed }\end{array}$ & & & -0.437 & 1.004 & 0.737 & 0.001 \\
\hline
\end{tabular}

Source: Authors' Calculation

\section{Effect of High and Low Periods of Death on Volatility of Returns for Individual Sectors}

Descriptive statistics for MANOVA reported in Table 7 specifies that there are two levels of independent variables which are high period of deaths and low period of deaths and 19 dependent variables which are the 19 sectors listed in the CSE. Sample size was 14 weeks of high period of deaths where reported weekly deaths were greater than 200 and 21 weeks of low periods of deaths where reported weekly deaths were less 
than 200. As per the descriptive statistics, the mean standard deviation of returns was reported to be higher in high period of deaths for 10 dependent variables which were Cement, Energy, Footwear, Textile, General Insurance, Services, Electrical and Engineering, Corporate Bonds, Mutual Funds and Miscellaneous sectors. Descriptive statistics also reported a standard deviation of volatility of returns.

Table 7: Descriptive Statistics for MANOVA

\begin{tabular}{|c|c|c|c|c|}
\hline & DEATH & Mean & Std. Deviation & $\mathbf{N}$ \\
\hline \multirow[t]{3}{*}{ Bank } & Week of High Death Rate & 0.019 & 0.005 & 14 \\
\hline & Week of Low Death Rate & 0.022 & 0.013 & 21 \\
\hline & Total & 0.021 & 0.010 & 35 \\
\hline \multirow[t]{3}{*}{ Cement } & Week of High Death Rate & 0.025 & 0.006 & 14 \\
\hline & Week of Low Death Rate & 0.022 & 0.018 & 21 \\
\hline & Total & 0.023 & 0.014 & 35 \\
\hline \multirow[t]{3}{*}{ Ceramic } & Week of High Death Rate & 0.022 & 0.008 & 14 \\
\hline & Week of Low Death Rate & 0.022 & 0.018 & 21 \\
\hline & Total & 0.022 & 0.014 & 35 \\
\hline \multirow[t]{3}{*}{ Energy } & Week of High Death Rate & 0.023 & 0.010 & 14 \\
\hline & Week of Low Death Rate & 0.020 & 0.012 & 21 \\
\hline & Total & 0.021 & 0.011 & 35 \\
\hline \multirow[t]{3}{*}{ Food } & Week of High Death Rate & 0.021 & 0.006 & 14 \\
\hline & Week of Low Death Rate & 0.024 & 0.013 & 21 \\
\hline & Total & 0.022 & 0.011 & 35 \\
\hline \multirow[t]{3}{*}{ Footwear } & Week of High Death Rate & 0.012 & 0.007 & 14 \\
\hline & Week of Low Death Rate & 0.012 & 0.013 & 21 \\
\hline & Total & 0.012 & 0.011 & 35 \\
\hline \multirow{3}{*}{ Paper } & Week of High Death Rate & 0.020 & 0.011 & 14 \\
\hline & Week of Low Death Rate & 0.023 & 0.021 & 21 \\
\hline & Total & 0.022 & 0.017 & 35 \\
\hline \multirow[t]{3}{*}{ Pharma } & Week of High Death Rate & 0.022 & 0.007 & 14 \\
\hline & Week of Low Death Rate & 0.026 & 0.013 & 21 \\
\hline & Total & 0.024 & 0.011 & 35 \\
\hline \multirow[t]{3}{*}{ Telecom } & Week of High Death Rate & 0.028 & 0.012 & 14 \\
\hline & Week of Low Death Rate & 0.030 & 0.033 & 21 \\
\hline & Total & 0.030 & 0.027 & 35 \\
\hline \multirow[t]{3}{*}{ Textile } & Week of High Death Rate & 0.023 & 0.009 & 14 \\
\hline & Week of Low Death Rate & 0.022 & 0.022 & 21 \\
\hline & Total & 0.022 & 0.018 & 35 \\
\hline \multirow[t]{3}{*}{ ICT } & Week of High Death Rate & 0.025 & 0.008 & 14 \\
\hline & Week of Low Death Rate & 0.026 & 0.016 & 21 \\
\hline & Total & 0.026 & 0.013 & 35 \\
\hline
\end{tabular}




\begin{tabular}{lllcl}
\hline & \multicolumn{1}{c}{ DEATH } & Mean & Std. Deviation & N \\
\hline Gen_Insurance & Week of High Death Rate & 0.041 & 0.012 & 14 \\
& Week of Low Death Rate & 0.031 & 0.018 & 21 \\
& Total & 0.035 & 0.016 & 35 \\
\hline Leasing & Week of High Death Rate & 0.029 & 0.007 & 14 \\
& Week of Low Death Rate & 0.023 & 0.019 & 21 \\
& Total & 0.026 & 0.015 & 35 \\
\hline Life Insurance & Week of High Death Rate & 0.029 & 0.007 & 14 \\
& Week of Low Death Rate & 0.023 & 0.019 & 21 \\
& Total & 0.026 & 0.015 & 35 \\
\hline Services & Week of High Death Rate & 0.020 & 0.005 & 14 \\
& Week of Low Death Rate & 0.018 & 0.014 & 21 \\
& Total & 0.019 & 0.011 & 35 \\
\hline Bond & Week of High Death Rate & 0.027 & 0.007 & 14 \\
& Week of Low Death Rate & 0.024 & 0.015 & 21 \\
& Total & 0.025 & 0.013 & 35 \\
\hline Mut_Fund & Week of High Death Rate & 0.014 & 0.006 & 14 \\
& Week of Low Death Rate & 0.007 & 0.005 & 21 \\
& Total & 0.010 & 0.007 & 35 \\
\hline Misc & Week of High Death Rate & 0.028 & 0.013 & 14 \\
& Week of Low Death Rate & 0.025 & 0.017 & 21 \\
& Total & 0.026 & 0.015 & 35 \\
\hline & Week of High Death Rate & 0.036 & 0.016 & 14 \\
& Week of Low Death Rate & 0.023 & 0.017 & 21 \\
& Total & 0.028 & 0.017 & 35 \\
\hline
\end{tabular}

Source: Authors' Calculation

Table 8 reports the $\mathrm{F}$ value estimated using four different multivariate tests of MANOVA. All the four tests, which were the Pillar's Trace, Wilks Lambda, Hotelling's Trace and Roy's Largest Foot found the model to be statistically significant at the 0.05 level of significance. Since there existed some uncertainty in meeting all the assumptions of MANOVA such as normality of distribution and homogeneity of variance assumption, the most robust multivariate test used in this study to interpret the results of MANOVA was Pillar's Trace. As per the Pillar's Trace multivariate test of MANOVA, the actual value of $F$ was 0.756 and the estimated value was 2.757 and the $F$ value was found to be statistically significant at the 0.05 level of significance since the estimated $P$ value was less than 0.05 . Based on this result, the third null hypothesis (H3o) which stated that there is no difference in volatility of returns of individual sectors due to high or low period of deaths was rejected. Hence, it can be inferred that high and low 
period of deaths had a significant impact on weekly volatility of returns for 19 sectors of the CSE.

Table 8: Multivariate Test for MANOVA

\begin{tabular}{|c|c|c|c|c|c|c|c|c|c|}
\hline Effect & & Value & $\mathbf{F}$ & $\begin{array}{l}\text { Hypothesis } \\
\text { df }\end{array}$ & $\begin{array}{l}\text { Error } \\
\text { df }\end{array}$ & Sig. & $\begin{array}{l}\text { Partial } \\
\text { Eta } \\
\text { Squared }\end{array}$ & $\begin{array}{l}\text { Noncent- } \\
\text { Parameter }\end{array}$ & $\begin{array}{c}\text { Observed } \\
\text { Power }\end{array}$ \\
\hline \multirow[t]{4}{*}{ Intercept } & $\begin{array}{l}\text { Pillai's } \\
\text { Trace }\end{array}$ & 0.964 & 24.035 & 18.000 & 16.000 & 0.000 & 0.964 & 432.634 & 1.000 \\
\hline & $\begin{array}{l}\text { Wilks' } \\
\text { Lambda }\end{array}$ & 0.036 & 24.035 & 18.000 & 16.000 & 0.000 & 0.964 & 432.634 & 1.000 \\
\hline & $\begin{array}{l}\text { Hotelling's } \\
\text { Trace }\end{array}$ & 27.040 & 24.035 & 18.000 & 16.000 & 0.000 & 0.964 & 432.634 & 1.000 \\
\hline & $\begin{array}{l}\text { Roy's } \\
\text { Largest } \\
\text { Root }\end{array}$ & 27.040 & 24.035 & 18.000 & 16.000 & 0.000 & 0.964 & 432.634 & 1.000 \\
\hline \multirow[t]{4}{*}{ DEATH } & $\begin{array}{l}\text { Pillai's } \\
\text { Trace }\end{array}$ & 0.756 & 2.757 & 18.000 & 16.000 & 0.023 & 0.756 & 49.619 & 0.893 \\
\hline & $\begin{array}{l}\text { Wilks' } \\
\text { Lambda }\end{array}$ & 0.244 & 2.757 & 18.000 & 16.000 & 0.023 & 0.756 & 49.619 & 0.893 \\
\hline & $\begin{array}{l}\text { Hotelling's } \\
\text { Trace }\end{array}$ & 3.101 & 2.757 & 18.000 & 16.000 & 0.023 & 0.756 & 49.619 & 0.893 \\
\hline & $\begin{array}{l}\text { Roy's } \\
\text { Largest } \\
\text { Root }\end{array}$ & 3.101 & 2.757 & 18.000 & 16.000 & 0.023 & 0.756 & 49.619 & 0.893 \\
\hline
\end{tabular}

Source: Authors' Calculation

Levene's Test reported in Table 8 checked for homogeneity of variance assumption of MANOVA across all 19 dependent variables. The equal variance assumption of MANOVA was satisfactory as the reported P value of Levene's test was more than the 0.05 level of significance for 13 sectors in the CSE except for Cement, ICT, Leasing, Life Insurance, Services and Electrical and Engineering. The third null hypothesis was rejected by all the multivariate tests of MANOVA even for 6 sectors which did not satisfy the homogeneity of variance assumption, hence the rejection of the null hypothesis for the 6 dependent variables was an acceptable finding using MANOVA. 
Table 9: Levene's Test of Equality of Error Variances

\begin{tabular}{lcccc} 
& F & df1 & df2 & Sig. \\
\hline Bank & 3.911 & 1.000 & 33.000 & 0.056 \\
Cement & 13.240 & 1.000 & 33.000 & 0.001 \\
Ceramic & 3.603 & 1.000 & 33.000 & 0.066 \\
Energy & 0.534 & 1.000 & 33.000 & 0.470 \\
Food & 2.048 & 1.000 & 33.000 & 0.162 \\
Footwear & 1.238 & 1.000 & 33.000 & 0.274 \\
Paper & 0.802 & 1.000 & 33.000 & 0.377 \\
Pharma & 1.587 & 1.000 & 33.000 & 0.217 \\
Telecom & 1.051 & 1.000 & 33.000 & 0.313 \\
Textile & 2.664 & 1.000 & 33.000 & 0.112 \\
ICT & 5.302 & 1.000 & 33.000 & 0.028 \\
Gen_Insurance & 3.283 & 1.000 & 33.000 & 0.079 \\
Leasing & 4.883 & 1.000 & 33.000 & 0.034 \\
Life_Insurance & 4.883 & 1.000 & 33.000 & 0.034 \\
Services & 5.697 & 1.000 & 33.000 & 0.023 \\
Elec \& Eng & 5.627 & 1.000 & 33.000 & 0.024 \\
Bond & 4.135 & 1.000 & 33.000 & 0.050 \\
Mut_Fund & 2.621 & 1.000 & 33.000 & 0.115 \\
Misc & 1.358 & 1.000 & 33.000 & 0.252 \\
\hline Sourc:Aurs'can & & & &
\end{tabular}

Source: Authors' Calculation

\section{CONCLUSION}

At the end of 2019, both the bourses in Bangladesh posted a negative index return of approximately $17 \%$ while bourses in five other emerging Asian countries recorded a positive growth for the same period. Indices touched rock bottom in both the Dhaka and Chittagong bourses despite different kinds of policy support and massive reforms by the government and regulators. The benchmark index of the premier bourse of the country, DSEX, reached as high as 5950 points on 24th January of 2020 thus recording a sharp rise by $10.48 \%$ and in the CSE all the share price index also recovered and rose by $2.1 \%$ from the downfall of the previous year. For the period between March 2020 to $1^{\text {st }}$ June of 2020, the DSEX fell sharply by 
9.3\% and CSEX plunged by $16.1 \%$ amid the fear and deaths due to Covid- 19 (Capital Market Development, 2020). A series of policy interventions and regulatory measures by the Securities and Exchange Commission of Bangladesh including closure of stock exchanges for more than two months failed to stabilize the stock market during the stated period. With the existing setback of liquidity crunch, money market volatility, rising non-performing loans and rising interest rates, poor tax revenue collection, aggressive bank borrowing by the government, depreciation of the Taka against the USD, declining outstanding foreign portfolio investment, sluggish earnings growth and poor payout ratio of listed companies and the Covid-19 crisis added further concerns to the diminishing investors' confidence, thus turning the market into the bearish mode (Mahmud, 2021).

During 2020, the highest single day gain was reported on 19th January when the CSE price index (CASPI) was 667 points. With the first reporting of Covid-19 infected cases during first week of March, large numbers of investors started binge selling and the CASPI index plunged by 769 points on 9th March 2020. The sharp decline in index value indicated that the Bangladesh stock market was not immune to the virus related shock that was hurting the global economy. Trading was stopped in both the Dhaka and Chittagong bourses starting from $26^{\text {th }}$ March 2020 since the containment measures for Covid-19 were in effect in Bangladesh for the same period. Following a two-month trading halt, on the day of opening, the CASPI index advanced by $1.245 \%$, thus signaling that investors had started trading with a positive approach as they were expecting the government ending the nationwide lockdown that started on 26th March, will revive economic growth. The introduction of a new circuit breaker during March to keep the bourses stable and the announcement of expansionary monetary policies also boosted investors' confidence, thus yielding a positive outcome on the indices as evidenced by the upward trend in both the DSEX and CASPI indices. On July 29, the Bangladesh Bank unveiled the monetary policy for FY 2020-2021, bringing down bank rates to $4 \%$ from 5\% and the repo rate from $5.25 \%$ to $4.75 \%$ to make funds available for banks at a cheaper rate. The upward rally in indices continued as investors continued their buying binge on large-cap stocks along with insurance and financial scripts as the economy was opening up gradually after the lockdown (Devnath, 2020). The all Share Price Index of the CSE stood at 13908.14 points at the end of August 2020, which was 16.32 percent higher than 11957.06 points at the 
end of July 2020. At the beginning of the fourth quarter of 2020 both the DSEX and CASPI indices reported, on an average, a positive growth on a daily basis (Trade Summary, CSE \& Trade Summary, DSE). According to the research report by Asia Frontier Capital, defying the odds of the Covid-19 health crisis situation, the Bangladesh stock market performance was highest in the world in terms of gains in the key indices during the third and fourth quarters of 2020. The report indicated that actions like attractive valuations, lower interest rates, smothered economic reopening after the lockdown to stop the spread of the virus, better remittance inflow and recovery in export earnings largely contributed to this performance of the stock market. The country's two stock exchanges started the year 2021 with a big leap, due to institutional investors' active participation. The DSEX index jumped by $4.01 \%$ on the first trading day of the year 2021 and crossed the 5600 marks point after 21 months. The CASPI index which is the benchmark index of the CSE also grew by $4.31 \%$ on the same day. The report suggests that the news of Beximco Pharmaceuticals signing an agreement with the government to bring Oxford-AstraZeneca vaccine to Bangladesh influenced the growth of the stock indices. This positive news reduced the anticipated uncertainty about economic recovery of the country and boosted investors' confidence about the macro-economic conditions (Mahmud, 2020, October 12).

This contextual evidence is also endorsed by the findings of this research. This study revealed that the sector-wise volatility of returns was significantly different between the high period of deaths and the low period of deaths during the Post-Covid time period which was between March 2020 to March 2021. Market indices performed better during the low period of deaths particularly the fourth quarter of 2020 and the first quarter of 2021(Capital Market Development, 2021). The study also found that the volatility of sector-wise returns differed significantly from each other over the 70 week duration extending from the Pre-Covid to Post-Covid time period. Average volatility of returns were found to be higher for certain sectors relative to others over this 70 week period. The sectors recording higher volatility of returns over the selected period are Cement, Ceramic, Paper, Textile, General Insurance, Leasing and Life insurance. The chart on trend analysis indicated that Bank, Food, Footwear, Leasing, Life Insurance, Electrical and Engineering and Mutual Funds sectors had the same level of volatility between the two time periods. Only four sectors, including 
Energy, Telecommunications, General Insurance and the Miscellaneous sectors displayed a higher Post-Covid volatility relative to the Pre-Covid context. Interestingly, for eight sectors including Cement, Ceramic, Paper, Pharmaceuticals, Textile, ICT, Services and Corporate bonds, the returns remained more volatile in the Pre-Covid context relative to the Post-Covid time period which is also supported by the moribund performance of indices in both the Chittagong and Dhaka bourses in 2019. The overall findings of this research indicated that the volatility of sector-wise securities returns were affected by the Covid-19 health crisis, however the magnitude effect was not found to be significant enough to identify the Pre-Covid volatility significantly different from the Post-Covid circumstances. The findings of this study are supported by research conducted by Kusumahadi and Permana (2021) who found the magnitude of effect of the Covid-19 Pandemic was small in fourteen countries which are the United States, Italy, Spain, Germany, China, France, Canada, South Korea, Brazil, Australia, Indonesia, South Africa, Singapore and Morocco. However, in-depth studies including a broad spectrum of data from both the bourses in Bangladesh would further enhance the suitability of this findings.

The stock market is a platform of borrowers and suppliers of funds. The containment measures for the Covid-19 pandemic resulted in lowering of export revenues, massive job cuts and pay cuts, lowering household expenditures and also forced millions to embrace zero or minimal income and poverty in Bangladesh. These economic and financial impacts of the pandemic affected both sides of the market i.e. demanders and suppliers of securities. Given the unprecedented level and nature of uncertainty triggered by the Covid-19 pandemic, this study anticipated that the stock market in Bangladesh would face complex and severe consequences. However, this research ascertained that the volatility of sector-wise returns was not significantly different between the Pre-Covid and Post-Covid time period. In fact, the Post-Covid volatility of many sectors remained lower compared to the Pre-Covid context as reported in the trend analysis. Amidst the pandemic situation the capital market reported a positive trend since June 2020. There are few factors that sparked the stock market of Bangladesh back into life after the two-months of complete halt of trading, including investors taking the opportunity to invest in undervalued stocks, decreased interest rates due to an expansionary monetary policy, timely initiatives by the new leadership of the stock market regulators, and increased co-relations among regulators. 
Along with the expansionary monetary policy in effect during the situation, the government of Bangladesh had announced a set of stimulus packages worth around $\$ 11.90$ billion i.e. Taka 1.011 trillion, to offset the COVID-19 shock on various sectors of the country and minimize the sufferings of the people hard hit by the nationwide shutdown enforced to fend off the deadly virus. Among the packages, the highest amount of Tk 300.00 billion was allocated for providing working capital facility to the affected industries and services sector organizations followed by Tk 200.00 billion stimulus package for supplying working capital to small and medium scale industrial enterprises. The other stimulus packages included agriculture subsidies with Taka 95.00 billion, agriculture refinancing scheme with Taka 50.00 billion, refinancing scheme for the low-income professional farmers and small businessmen with Taka 30.00 billion. Besides, stimulus packages the government also announced loan facilities of Tk 50.00 billion against special funds for export-oriented industries and Pre-Shipment Credit Refinance Scheme with Taka 50.00 billion (Imam, 2020 May 29). Despite the uncertainty created by COVID-19, the outlook for Bangladesh's economy remains positive as per the World Bank's report. The country's economy is showing promising signs of recovery backed by a rebound in exports, strong remittance inflows, and the ongoing vaccination program (World Bank, 2021). The result is reflected in the GDP of the country which grew by 5.24 percent during 2019-20 according to the Bangladesh Bureau of Statistics (Mahmood, 2020, September 5). The growth of the economy also boosted investors' confidence on economic recovery and the impact of which is visible in the rebounding of the stock market indices during the last quarter of 2020.

\section{REFERENCES}

Baek, S., Mohanty, S. K., \& Glambosky, M. (2020). COVID-19 and stock market volatility: An industry level analysis. Finance Research Letters, Elsevier, 37, 101748.

Bahrini, R., \& Assaf, F. (2020). Impact of the novel coronavirus on stock market returns: Evidence from GCC countries. Quantitative Finance and Economics, 4(4), 640-652. 
Beck, T. \& Levine, R. (2004). Stock market, banks and growth: Panel evidence. Journal of Banking \& Finance, Elsevier, 28(3), 423-442.

Bora, D., \& Basisth, D. (2021). The outbreak of COVID-19 pandemic and its impact on stock market volatility: Evidence from a worst-affected economy. Journal of Public Affairs, e2623.

Devnath, A (2020, May 31). Stocks Surge in Bangladesh as Exchanges Reopen After Two Months. Bloomberg. Retrieved from https://www. bloombergquint.com/onweb/stocks-gain-in-bangladesh-as-exchangesreopen-after-two-months

Greenspan, A. (2000). Global challenges. Speech at the Financial Crisis Conference, Council on Foreign Relations, New York, 12 July. Retrieved from https://www.federalreserve.gov/boarddocs/speeches/ 2000/20000712.htm

Haque, S., \& Chowdhry, T. A., (2020). Impact of Covid-19 in Bangladesh stock market. Asian Finance \& Banking Review, 4(2), 22-33.

Hong, H., Bian, Z., \& Lee, C.C. (2021). COVID-19 and instability of stock market performance: Evidence from the U.S. Financial Innovation, $7(12), 1-18$.

Ibrahim, I., Kamaludin, K., \& Sundarasen, S. (2020). COVID-19, Government Response, and Market Volatility: Evidence from the AsiaPacific. Developed and Developing Market Economies, 8(4), 105-127.

Imam, S. H. (2020, May 29). COVID-19: Govt so far announces $\$ 11.90 \mathrm{~b}$ stimulus packages. Financial Express. Retrieved from https://thefinan cialexpress.com.bd/economy/bangladesh/covid-19-govt-so-farannounces-1190b-stimulus-packages- 1590759538

Kusumahadi, T. A., \& Permana, C. F. (2021.) Impact of COVID-19 on global stock market volatility. Journal of Economic Integration, 36(1), 20-45.

Levine, R. \& Zervos, S. (1998). Stock markets, banks, and economic growth. American Economic Review, 88, 537-558. 
Mahmood, M. (2020, September 5). On Bangladesh GDP in the time of Coronavirus. Financial Express. Retrieved from https:// thefinancialexpress.com.bd/economy/bangladesh/covid-19-govt-sofar-announces-1190b-stimulus-packages-1590759538

Mahmud, N (2020, October 12). Q3 2020: Bangladeshi capital market deemed Asia's best. Dhaka Tribune. Retrieved from https://www. dhakatribune.com/business/2020/10/12/bangladeshi-capital-marketperforms-best-in-world-in-q3

Mahmud, N. (2020, January 2). As Bangladesh stock market goes down, bourses in emerging Asia go up. Dhaka Tribune. Retrieved from https:// www.dhakatribune.com/business/stock/2020/01/02/as-bangladeshstock-market-goes-down-bourses-in-emerging-asia-go-up

Mahmud, N. (2021, January 3). DSE had best performance among Asian bourses in 2020. Dhaka Tribune. Retrieved from https://www. dhakatribune.com/business/2021/01/03/dse-had-best-performanceamong-asian-bourses-in-2020

Nicola, M., Alsafi, Z., Sohrabi, C., Kerwan, A., Al-Jabir, H., Iosifidis, C., Agha, M., \& Agha, R. (2020). The socioeconomic implications of the coronavirus pandemic (COVID-19): A review. International Journal of Surgery, 78, 185-193.

Rajan, R. G. \& Zingales, L. (2001). Financial Systems, Industrial Structure, and Growth. Oxford Review of Economic Policy, 17(4), 467-82.

Research Department of Bangladesh Bank (2020). Capital Market Development in Bangladesh, August 2020. Retrieved from https:// bb.org.bd/pub/month ly/capital_market/report_aug2020.pdf

Research Department of Bangladesh Bank (2021). Capital Market Development in Bangladesh, January 2021. Retrieved from https:// www.bb.org.bd/pub/monthly/capital_market/jan_2021.pdf

The Chittagong Chamber of Commerce and Industry. (n.d.). Economic Landscape of Chattogram. Retrieved from https://www. chittagongchamber.com/elc.php 
Trade Summary, Chittagong Stock Exchange. (n.d.). Retrieved from https:// www.cse.com.bd/market/historicaldata

Trade Summary, Dhaka Stock Exchange. (n.d.). Retrieved from https:// www.dse.com.bd/data_archive.php

Uddin, M., Chowdhury, A., Anderson, K., \& Chaudhuri, K. (2021). The effect of COVID - 19 pandemic on global stock market volatility: Can economic strength help to manage the uncertainty? Journal of Business Research, 128, 31-44.

World Bank (2021, April 12). Bangladesh Economy Shows Early Signs of Recovery Amid Uncertainties. Retrieved from https://www.worldbank. org/en/news/press-release/2021/04/12/bangladesh-economy-showsearly-signs-of-recovery-amid-uncertainties

Yousef, I. (2020). Spillover of COVID-19: Impact on Stock Market Volatility. International Journal of Psychosocial Rehabilitation, 24(6), 18069-18081.

Zaiontz, C. (2020). Null and alternate hypothesis. Retrieved from https:// www.real-statistics.com/hypothesis-testing/null-hypothesis/ 